\title{
Purinergic regulation of angiogenesis by human breast carcinoma-secreted nucleoside diphosphate kinase
}

\author{
SM Rumjahn', MA Javed', N Wong', WE Law' and ILO Buxton*,I \\ 'Department of Pharmacology MS3 18, University of Nevada School of Medicine, 1664 N Virginia Street, Reno, NV 89557, USA
}

\begin{abstract}
MDA-MB-435S human breast cancer cells (435S) secrete nucleoside diphosphate kinase (NDPK) that supports metastases and is inhibited by epigallocatechin gallate (EGCG) and ellagic acid (EA). We hypothesise that $435 \mathrm{~S}$ cell-secreted NDPK-B supports tumour formation by modulating ATP levels locally to activate endothelial cell (EC) P2Y receptor-mediated angiogenesis. Epigallocatechin gallate $\left(\mathrm{IC}_{50}=8-\mathrm{IO} \mu \mathrm{M}\right)$ and $\mathrm{EA}\left(\mathrm{IC}_{50}=2-3 \mu \mathrm{M}\right)$ suppressed $435 \mathrm{~S}$ cell growth, but had less effect on human $\mathrm{CD} 3 \mathrm{I}^{+} \mathrm{EC}$ growth. Epigallocatechin gallate $\left(\mathrm{IC}_{50}=\mid \mathrm{I} \mu \mathrm{M}\right)$ and $\mathrm{EA}\left(\mathrm{IC}_{50}=\mid \mu \mathrm{M}\right)$ also prevented $\mathrm{CD} 3 \mathrm{I}^{+}$EC tubulogenesis on Matrigel ${ }^{\mathrm{TM}}$. 435S cellconditioned media induced tubulogenesis in a cell number, time, and nucleotide-dependent manner. Ellagic acid (I $\mu \mathrm{M}$ ), but not equimolar EGCG, reduced cell number-dependent angiogenesis. P2Y, receptor activation by NDPK-generated nucleotide (I $00 \mu \mathrm{M}$ ATP) or by $10 \mu \mathrm{M}$ 2-methyl-thio-ATP (2MS-ATP) promoted tubulogenesis on collagen and was blocked by the P2Y, antagonist MRS2179 (I0 $\mu \mathrm{M})$. Physiological amounts of purified as well as $435 \mathrm{~S}$ cell-secreted NDPK also promoted angiogenesis that was attenuated by NDPK depletion or $10 \mu \mathrm{M}$ MRS2 179, indicating a P2Y, receptor-mediated pathway. These results support the notion that secreted NDPK mediates angiogenesis via P2Y receptor signalling and suggests that novel inhibitors of NDPK may be useful as therapeutics.

British Journal of Cancer (2007) 97, 1372- 1380. doi:I0.1038/sj.bjc.66040I9 www.bjcancer.com

Published online 16 October 2007

(C) 2007 Cancer Research UK
\end{abstract}

Keywords: breast cancer; tumour angiogenesis; nucleoside diphosphate kinase; polyphenolic compounds; P2Y receptors

The onset of tumour vascularisation, the 'angiogenic switch', supplies the tumour with nutrients and oxygen that promote growth. It is known that tumours in a pre-vascularised state are unable to grow beyond $2-3 \mathrm{~mm}^{3}$ (approximately $10^{5}-10^{6}$ cells) in size where a balance between active proliferation and apoptosis keeps the tumour in an arrested state of growth (Holmgren et al, 1995). Conventional treatment modalities targeting the genetically instable cancer cells are burdened with toxicity and the emergence of drug-resistant cell types. Directly targeting the genetically stable vascular endothelial cells (ECs) involved in tumour-mediated angiogenesis has shown promise when co-administered with conventional cancer therapies (Clinical Trials, 2006). It has been suggested that angiogenic therapies initially normalise the vasculature and thus sensitise tumours to concurrently administered chemo/radiotherapies resulting in synergistic outcomes (Jain, 2001; Tong et al, 2004). Since women who succumb to breast cancer have often undergone surgery to remove the primary tumour, antiangiogenic therapies may be considered essential in combating the metastatic spread often seen years later.

Nucleoside diphosphate kinase (NDPK) (EC 2.7.4.6), the protein product of gene $n m 23$, was first described as an intracellular 'housekeeping' enzyme, which covalently transfers the $\gamma$-phosphate from a nucleoside triphosphate to a nucleoside diphosphate. While expression of $n m 23-H 1$ (NDPK-A) and $n m 23-H 2$ (NDPK-B) have been examined, less attention to their enzymatic function in cancer

*Correspondence: ILO Buxton; E-mail: ibuxton@medicine.nevada.edu Revised 5 September 2007; accepted 10 September 2007; published online 16 October 2007 and metastasis has been considered. Nucleoside diphosphate kinase is known to be distributed in the cytosol and plasma membrane of cells, as well as the nucleus (Bertheau et al, 1994) where the NDPK-B isoform functions as PuF, a c-MYC transcription factor (Postel, 2003). Non metastatic clone 23 gene, $n m 23$, was first observed in murine carcinoma cell lines and said to negatively correlate with a cancer's metastatic potential (Roymans et al, 2002), although there is evidence to the contrary (Postel, 2003). We have shown that both MDA-MB-435S and -231 metastatic human breast carcinoma cells secrete NDPK-B into their surrounding environment when cultured in vitro (Anzinger et al, 2001). Nucleoside diphosphate kinase is secreted, despite the lack of a signal sequence, probably via non-classical export as has previously been reported with proangiogenic fibroblast growth factors 1 and 2 (FGF-1 and FGF-2) (Nickel, 2003). The transphosphorylation activity of NDPK-B has been reported to promote the metastatic potential of human melanoma cells (Hamby et al, 2000).

The anticarcinogenic potential of catechins (polyphenols found in green tea) was first observed and reported over a decade ago. Epigallocatechin gallate (EGCG) has been identified as the major catechin in green tea and shown to inhibit both the growth of various cancers (Liang et al, 1999; Suganuma et al, 1999), and angiogenesis (Cao and Cao, 1999; Singh et al, 2002). We have previously shown that EGCG and ellagic acid (EA) are more potent inhibitors of NDPK activity than known nucleoside analogues (Malmquist et al, 2001) and have suggested a role for NDPK inhibition in the management of metastasis (Anzinger et al, 2001). A role for NDPK activity in blood vessel regulation is known. The Nucleotide Axis Hypothesis posits that ecto-NDPK on vascular ECs 
facilitates the regulation of extracellular nucleotide levels (e.g., ATP) (Buxton et al, 2001; Kaiser and Buxton, 2002). Since perturbing the regulation of nucleotide levels has been shown to impair angiogenesis (Goepfert et al, 2001; Moser et al, 2001), we hypothesise that extracellular NDPK takes an advantage of nucleotide signalling on vascular ECs and promotes pathological angiogenesis.

Heterotrimeric G-protein-coupled ATP receptors (P2Y) are recognised as integral modulators of platelet aggregation and blood flow regulation. Extracellular ATP activates P2Y receptors on vascular ECs to release vasoactive mediators such as nitric oxide, prostacyclin, and additional ATP (Yang et al, 1994; Buxton et al, 2001) which can also elicit angiogenic effects (Kashiwagi et al, 2005). Here, we provide evidence that human breast cancer cellsecreted NDPK promotes EC tubulogenesis in vitro. This supports our hypothesis that NDPK-mediated increases in extracellular ATP levels by breast tumour cells provide a mechanistic basis by which targeted therapeutics can prevent tumour growth and angiogenesis.

\section{MATERIALS AND METHODS}

\section{Cell culture}

The human breast cancer cell line MDA-MB-435S (435S) was purchased from the American Type Culture Collection (Manassas, VA, USA). Human cardiac ECs were previously isolated by fluorescence-activated cell sorting (FACS) for CD31 (PECAM) and immortalised by human telomerase reverse transcriptase (hTRT) - referred to as CD31 ${ }^{+}$cells. Unless specifically stated, both cell types were maintained and incubated in Dulbecco's modified Eagle's medium (DMEM) (HyClone, Logan, UT, USA) supplemented with $10 \%$ fetal bovine serum (FBS) (Atlanta Biological, Lawrenceville, GA, USA), penicillin-streptomycin, $\left(1500 \mathrm{Ul}^{-1}-100 \mathrm{mgl}^{-1}\right.$ ) and $0.5 \mathrm{mgl}^{-1}$ Fungizone (Invitrogen, Carlsbad, CA, USA) at $37^{\circ} \mathrm{C}$ in a humidified $5 \% \mathrm{CO}_{2} / 95 \%$ air atmosphere.

\section{Effect of EGCG and EA on MDA-MB-435S and CD31 ${ }^{+}$cell growth}

To determine if EGCG and/or EA (Sigma, St Louis, MO, USA) inhibit $435 \mathrm{~S}$ cell growth, $1.2 \times 10^{5}$ cells per well were seeded onto six-well tissue culture plates and incubated in the presence of EGCG or EA $(0.3-30 \mu \mathrm{M})$ for 2-5 days. For longer incubation periods (i.e., days 4 and 5) culture media were replaced after $72 \mathrm{~h}$ with fresh media containing appropriate ECGC or EA concentrations. To determine if EGCG and/or EA inhibit CD31 ${ }^{+}$cell growth, $9.6 \times 10^{4}$ cells per well were first seeded onto six-well tissue culture plates and incubated for $24 \mathrm{~h}$. Culture media were then replaced with fresh media containing EGCG or EA $(0.3-10 \mu \mathrm{M})$ and incubated for $24 \mathrm{~h}$. At desired treatment end points, EGCG and EA (2-5 days and $24 \mathrm{~h}$, respectively) treated cells were counted using a Coulter Z1 cell counter (Coulter Corp, Hialeah, FL, USA) and compared to non-treatment controls.

\section{In vitro angiogenesis scoring technique}

$\mathrm{CD} 1^{+}$cell tubulogenesis (i.e., tubule-like formation in culture) was quantified using a high-resolution digital camera (FujiPro 2; 12 mega pixel) attached to a Nikon 300 inverted microscope to document $\mathrm{CD} 31^{+}$cell tubule-like formations. An angiogenesis score was obtained by analysing digital images $(\times 100)$ collected from the central pointing corners of quadrants I-IV in each well and averaging the four scores. Each angiogenesis score represents the product of mean number of branch points multiplied by mean branch length multiplied by mean cell surface area (illustrated in Figure 1). Morphometry (in pixels) was performed using
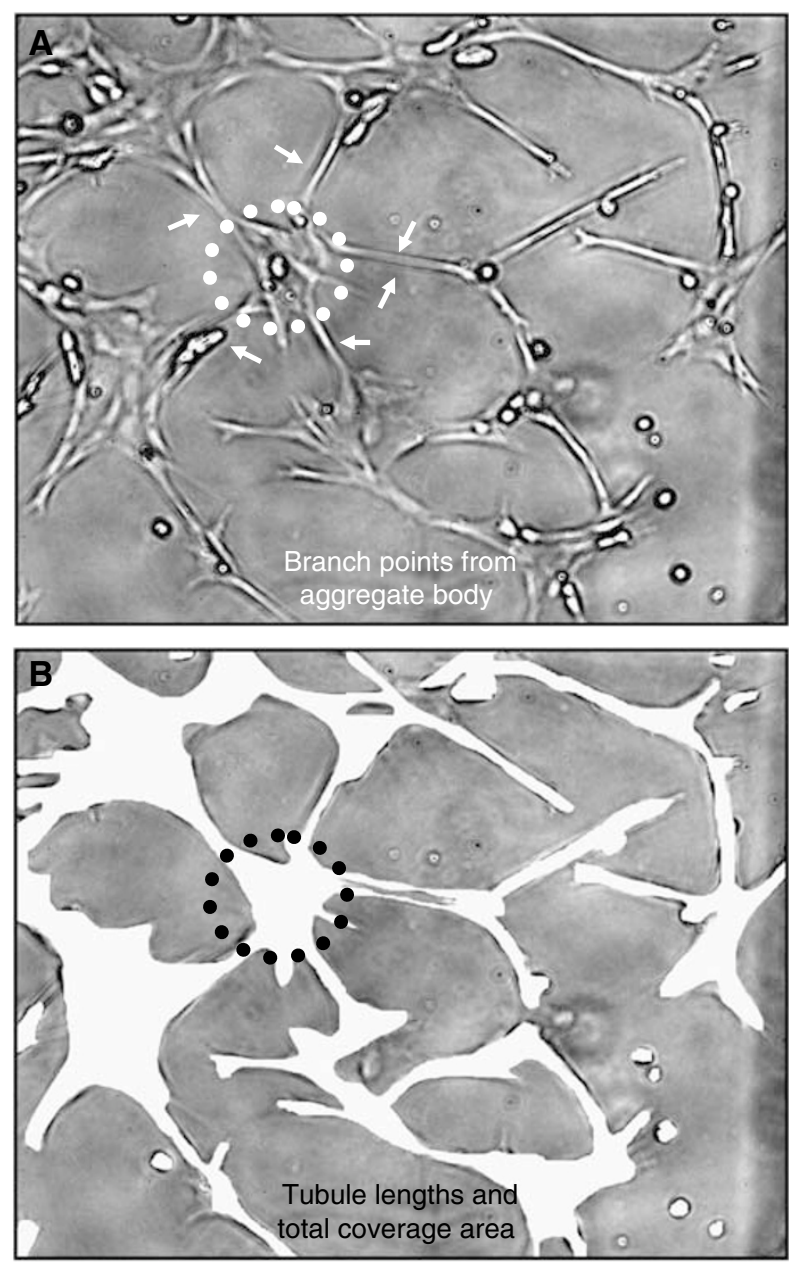

Figure I Angiogenesis scoring. (A) Tubule lengths $(I)$ and number of branch points (bp). (B) Endothelial cell (EC) surface area (a). Relative angiogenesis score $(s)=b p \times 1 \times a$. Photographs were imaged at a magnification of $\times 100$

MetaMorph image analysis software (V4.01; Universal Imaging Corporation, Downingtown, PA, USA). The lengths of tubule-like formations were measured for all completely visible connections between edges of aggregate bodies (Figure 1A). The number of branch points connecting one aggregate body to other aggregate bodies (usually $1-3$ ) was counted when the complete connection was within view of the image (Figure $1 \mathrm{~A})$. The total $\mathrm{CD} 31^{+}$cell surface area was also determined from these images (Figure 1B). Number of branch points $(b p)$, length $(l)$, and cell surface area $(a)$ were multiplied to produce a relative angiogenesis score $(s)$. Thus, $s=b p \times l \times a$.

\section{Effect of EGCG and EA on angiogenesis}

Four-well glass slide chambers were coated with a thin layer $(\sim 10 \mu \mathrm{l})$ of Matrigel $^{\mathrm{TM}}$ (BD Biosciences, Bedford, MA, USA) and allowed to solidify at $37^{\circ} \mathrm{C} / 5 \% \mathrm{CO}_{2}$ for $30 \mathrm{~min}$. To determine if EGCG and/or EA inhibit CD31 ${ }^{+}$cell tubulogenesis, $5 \times 10^{4}$ cells were first seeded onto four-well glass slide chambers coated with Matrigel and allowed to attach for $30 \mathrm{~min}$ at $37^{\circ} \mathrm{C} / 5 \% \mathrm{CO}_{2}$. The test substances EGCG or EA $(0.3-30 \mu \mathrm{M})$ were then added to the individual wells as appropriate and incubated with $\mathrm{CD} 31^{+}$cells for $5.5 \mathrm{~h}$. The antiangiogenic drug endostatin (Sigma), $0.1-$ $1.0 \mu \mathrm{g} \mathrm{ml}^{-1}$, was used as a positive control. Non-treatment controls 
were performed for normalisation and comparison of EGCG and EA effects on in vitro angiogenesis.

\section{Effect of MDA-MB-435S cell-conditioned media on angiogenesis}

To determine if secreted molecules from $435 \mathrm{~S}$ cells promote $\mathrm{CD} 31^{+}$in vitro angiogenesis, $435 \mathrm{~S}$ cells were seeded onto Transwell $^{\mathrm{TM}}$ tissue culture inserts $(3.0 \mu \mathrm{m}$ pores; Corning, Acton, MA, USA) for incubation times up to $24 \mathrm{~h}$. These various conditioned media were examined via the above described $\mathrm{CD} 1^{+}$cell Matrigel tubulogenesis assay using 24-well tissue culture plates. Briefly, $435 \mathrm{~S}$ cell number $\left(1.5-6 \times 10^{4}\right.$ cells incubated for $12 \mathrm{~h})$ and conditioning time $\left(6 \times 10^{4}\right.$ cells incubated for $30 \mathrm{~min}$ to $24 \mathrm{~h}$ ) were used as experimental variables. At their incubation end points, the various conditioned media were frozen at $-30^{\circ} \mathrm{C}$ and later assessed for their effects on in vitro angiogenesis.

Effect of EGCG and EA on MDA-MB-435S cell-conditioned media promoted angiogenesis

The conditioned media from $1.5 \times 10^{4}$ to $6 \times 10^{4} 435 \mathrm{~S}$ cells incubated for $12 \mathrm{~h}$ was further investigated with the addition of either $1 \mu \mathrm{m}$ EGCG or EA. These experiments were conducted using the $\mathrm{CD} 31^{+}$cell Matrigel tubulogenesis assay on 24-well tissue culture plates. Endostatin $\left(1.0 \mu \mathrm{g} \mathrm{ml}^{-1}\right)$ was used as a positive antiangiogenic control. Non-treatment controls were performed for normalisation and comparison.

\section{Effect of apyrase on MDA-MB-435S cell-conditioned media promoted angiogenesis}

The conditioned media from $6 \times 10^{4} 435 \mathrm{~S}$ cells incubated for $60 \mathrm{~min}$ was also further investigated with the addition of potato apyrase (grade 1; Sigma; EC 3.6. 1.5). Briefly, the $435 \mathrm{~S}$ cellconditioned media were incubated in a final concentration of $0.75 \mathrm{U}$ apyrase per millilitre conditioned media for $5 \mathrm{~min}$ at $37^{\circ} \mathrm{C}$ (1 U liberates $1.0 \mu \mathrm{mol}$ orthophosphate from ATP or ADP per min at $\left.\mathrm{pH} 6.5,30^{\circ} \mathrm{C}\right)$. This conditioned media pretreated with apyrase was then observed in the $\mathrm{CD} 31^{+}$cell Matrigel tubulogenesis assay onto 24-well tissue culture plates. Non-treatment controls were performed for normalisation and comparison.

\section{Effect of ATP and 2-methyl-thio-ATP on angiogenesis}

The following experiments were performed with a lower concentration of FBS supplementation (2 vs 10\%) and collagen instead of Matrigel to rule out the role of angiogenic factors present in Matrigel to more clearly distinguish the amount of proangiogenic stimulation attributed to $\mathrm{P} 2 \mathrm{Y}$ receptor activation alone. To determine if 2-methyl-thio-ATP (2MS-ATP) and/or ATP (Sigma) stimulate in vitro angiogenesis, $3 \times 10^{4} \mathrm{CD} 31^{+}$cells per well were first seeded onto 24-well tissue culture plates coated with $1 \mathrm{mg} \mathrm{ml}^{-1}$ collagen (Rat type I; BD Biosciences) and allowed to attach for $30 \mathrm{~min}$. The $\mathrm{P} 2 \mathrm{Y}$ receptor agonists $2 \mathrm{MS}-\mathrm{ATP}\left(\mathrm{P} 2 \mathrm{Y}_{1} \mathrm{R}\right.$; $10 \mu \mathrm{M})$ and ATP $\left(\mathrm{P}_{2} \mathrm{Y}_{1 / 2} \mathrm{R} ; 100 \mu \mathrm{M}\right)$ were added to their respective wells and incubated with $\mathrm{CD} 31^{+}$cells for $24 \mathrm{~h}$. CD $31^{+}$cell tubulogenesis was also observed in the presence of $10 \mu \mathrm{M}$ MRS2179 (P2Y ${ }_{1} \mathrm{R}$ antagonist; Sigma) with either $10 \mu \mathrm{M} 2 \mathrm{MS}-\mathrm{ATP}$ or $100 \mu \mathrm{M}$ ATP. Endothelial growth medium-2 (EGM-2 ${ }^{\mathrm{TM}}$; Clonetics, East Rutherford, NJ, USA) was used as a positive control to confirm that this modified assay could successfully detect angiogenic stimulation. Non-treatment controls were performed for normalisation and comparison. This experiment was repeated with $2 \times 10^{4} \mathrm{CD} 31^{+}$cells per well and incubated for a longer duration of $72 \mathrm{~h}$.

\section{Preparation of human breast carcinoma secreted NDPK} extract

MDA-MB-435S cells were grown to $\sim 75 \%$ confluence in T150 tissue culture flasks and then washed $\times 3$ with room air Krebs buffer (RAK) containing (in $\mathrm{mM}) 120 \mathrm{NaCl}, 5 \mathrm{KCl}, 0.587, \mathrm{KH}_{2} \mathrm{PO}_{4}$, $0.589 \mathrm{Na}_{2} \mathrm{HPO}_{4}, 2.5 \mathrm{MgCl}_{2}, 20 \alpha$-D-glucose, $2.5 \mathrm{CaCl}_{2}, 25$ Tris, and 5 $\mathrm{NaHCO}_{3}$. The cells were then slowly rocked and incubated in RAK at $37^{\circ} \mathrm{C}$ for $90 \mathrm{~min}$. This RAK containing secreted NDPK-B was concentrated for $30 \mathrm{~min}$ at $4{ }^{\circ} \mathrm{C}$ and $2000 \mathrm{~g}$ using Amicon Ultra- 15 $10 \mathrm{kDa}$ Centrifugal Filters (Millipore Corporation, Bedford, MA, USA). The remaining liquid captured above the $10-\mathrm{kDa}$ mark was once again filtered as described above. The concentrated $(\sim 200$ fold) $435 \mathrm{~S}$ cell-secreted NDPK extract was frozen at $\left(-80^{\circ} \mathrm{C}\right)$ and used in subsequent angiogenesis experiments. The average protein concentration for $1 \times \mathrm{NDPK}$ extract $\left(19.23 \mu \mathrm{g} \mathrm{ml}^{-1}\right)$ was used to mimic the approximate amount of secreted NDPK-B seen in the conditioned media of $\sim 75 \%$ confluent $435 \mathrm{~S}$ carcinoma cell cultures. Nucleoside diphosphate kinase transphosphorylation activity; ATP production from GTP donor and ADP acceptor was measured using a luciferin-luciferase ATP detection assay (Sigma). Using only ADP and no GTP donor in our activity assay showed no ATP production, indicating that adenylate kinase activity was not responsible for the ATP production observed (not shown).

\section{Effect of purified NDPK on angiogenesis}

To determine if purified NDPK promotes in vitro angiogenesis, $3 \times 10^{4} \mathrm{CD}_{3}{ }^{+}$cells per well were first seeded onto 24 -well tissue culture plates coated with $1 \mathrm{mg} \mathrm{ml}^{-1}$ collagen (Rat type I) and allowed to attach for $30 \mathrm{~min}$. Semi-purified bovine liver NDPK (Sigma) and subsequent affinity purified NDPK transphosphorylation activity levels; as measured using a luciferin-luciferase ATP detection assay were used to match the activity level of $1 \times 435 \mathrm{~S}$ cell-secreted NDPK extract. This purified NDPK with or without nucleotide donor and acceptor $(300 \mu \mathrm{M}$ GTP and $30 \mu \mathrm{M}$ ADP, respectively) were then added to wells and incubated with the $\mathrm{CD} 31^{+}$cells for $24 \mathrm{~h}$. EGM-2 was used as a positive control, while non-treatment controls were performed for normalisation and comparison.

\section{Effect of MRS2179 on NDPK extract induced angiogenesis}

To determine if MRS2179 ( $\mathrm{P} 2 \mathrm{Y}_{1} \mathrm{R}$ antagonist) reduces the degree which $435 \mathrm{~S}$ cell-secreted NDPK extract promotes in vitro angiogenesis, $3 \times 10^{4} \mathrm{CD} 31^{+}$cells per well were first seeded onto 24 -well tissue culture plates coated with $1 \mathrm{mg} \mathrm{ml}^{-1}$ collagen (Rat type I) and allowed to attach for $30 \mathrm{~min} .1 \times$ NDPK extract with or without $10 \mu \mathrm{M}$ MRS2179 was then incubated with the CD31 ${ }^{+}$cells for $24 \mathrm{~h}$. EGM-2 was used as a positive control, while nontreatment controls were performed for normalisation and comparison. This experiment was also repeated with $2 \times 10^{4} \mathrm{CD} 31^{+}$cells per well in experiments lasting $72 \mathrm{~h}$.

\section{Statistical analyses}

All graphs were prepared using Prism Graphing Software (V4.03; GraphPad Software, San Diego, CA, USA) and statistical analyses were performed using InStat Statistical Software (V3.0; GraphPad Software), with $P<0.05$ considered to be statistically significant. All growth and angiogenesis scores were tested for statistical significance using ANOVA and Kruskal-Wallis multiple comparisons post-test unless otherwise stated. Data points and error bars represent means \pm s.e.m. ${ }^{\star} P<0.05 ; \quad{ }^{*} P<<0.01 ;{ }^{* *} P<0.001$ (vs negative control); ${ }^{+} P<0.05$ (EGCG vs EA); ${ }^{\#} P<0.05 ;{ }^{\#} P<0.01$ ( $v s$ 435S cell stimulation). 


\section{RESULTS}

\section{Epigallocatechin gallate and EA suppress MDA-MB-435S} cell growth

435 cells incubated with $3 \mu \mathrm{M}$ EGCG over 5 days inhibited growth $\sim 10-20 \%$, while equimolar EA was more effective with $\sim 50-60 \%$ growth suppression. Ellagic acid but not EGCG significantly inhibited cell growth at $3 \mu \mathrm{M}$ when compared to non-treatment controls $(P \leqslant 0.001$; Figure $2 \mathrm{~A})$. The addition of $10 \mu \mathrm{M}$ EGCG for 5 days inhibited growth $\sim 45-65 \%$, while equimolar EA was more effective producing $\sim 80-90 \%$ suppression. Both EA and EGCG treatments significantly impeded cell growth at $10 \mu \mathrm{M}$ when compared to non-treatment controls ( $P \leqslant 0.05$; Figure $2 \mathrm{~B})$. 435S cells incubated with $0.3-30 \mu \mathrm{M}$ EGCG or EA over 2 days produced dose-dependent inhibition of growth with an apparent $\mathrm{IC}_{50}$ for EGCG of $\sim 8 \mu \mathrm{M}$ and an $\mathrm{IC}_{50}$ for EA of $\sim 2 \mu \mathrm{M}$ (day $5 \mathrm{EGCG} \mathrm{IC}_{50}$ of $\sim 10 \mu \mathrm{M}$ and $\mathrm{EA} \mathrm{IC}_{50}$ of $\sim 3 \mu \mathrm{M}$; data not shown). Treatment with $\mathrm{EA} \geqslant 1 \mu \mathrm{M}$ over 2 days significantly suppressed cell growth when compared to non-treatment control $(P \leqslant 0.05$; Figure $2 \mathrm{C})$ and at a $\sim 1 / 2$ log higher potency than EGCG $(3 \mu \mathrm{M} v s 10 \mu \mathrm{M}=$ approximately $60 \%$ inhibition). At micromolar concentrations, both agents were cytostatic rather than cytotoxic since cells regrew when drug was removed.

\section{Epigallocatechin gallate and EA suppress human EC growth and tubule-like formations on Matrigel}

$\mathrm{CD} 1^{+}$cells incubated with $0.3-10 \mu \mathrm{M}$ EGCG or EA for $24 \mathrm{~h}$ produced dose-dependent inhibition of growth. The addition of EGCG or EA significantly suppressed growth $\sim 35-45 \%$ at concentrations $\geqslant 3 \mu \mathrm{M}$ when compared to non-treatment control $(P \leqslant 0.05$; Figure $3 \mathrm{~A})$. $\mathrm{CD} 31^{+}$cells incubated on Matrigel with $0.3-$ $30 \mu \mathrm{M}$ EGCG or EA produced dose dependent inhibition of in vitro angiogenesis with an apparent $\mathrm{IC}_{50}$ for EGCG of $\sim 11 \mu \mathrm{M}$ and a more potent $\mathrm{IC}_{50}$ for EA of $\sim 1 \mu \mathrm{M}$. Addition of EA significantly reduced angiogenesis when compared to non-treatment control $(P \leqslant 0.01$; Figure $3 \mathrm{~B}$ and $\mathrm{C})$. Unlike growth inhibition, EA suppressed $\mathrm{CD} 31^{+}$cell tubulogenesis at approximately one log lower concentration than EGCG $(3 \mu \mathrm{M} v s 30 \mu \mathrm{M}=\sim 70 \%$ inhibition). Endostatin, the antiangiogenic control, produced dose dependent and significant inhibition of angiogenesis at $1 \mu \mathrm{g} \mathrm{ml}^{-1}$ comparable to concentrations $\geqslant 3 \mu \mathrm{M}$ of EGCG and EA $(P \leqslant 0.05$; data not shown).

\section{MDA-MB-435S conditioned media promotes in vitro angiogenesis in a time-, cell number-, and nucleotide-dependent manner}

We examined the effect of 435 S cell-conditioned media on $\mathrm{CD} 31^{+}$ cell tubulogenesis and its inhibition by polyphenolic compounds. Media containing secreted NDPK-B (conditioned media) were collected using a Transwell ${ }^{\mathrm{TM}}$ apparatus seeded with $435 \mathrm{~S}$ cells. CD31 ${ }^{+}$cells incubated with 12 -h conditioned media (varying $435 \mathrm{~S}$ cell number from $1.5 \times 10^{4}$ to $6 \times 10^{4}$ ) on Matrigel demonstrated a progressive induction of angiogenesis with increasing numbers of $435 \mathrm{~S}$ cells. A ratio of $\geqslant 75$ MDA-MB- $435 \mathrm{~S}$ cells per microlitre $\left(4.5 \times 10^{4}\right.$ cells $)$ significantly promoted angiogenesis at least twofold when compared to control media conditioned without breast cancer cells $(P \leqslant 0.05$; Figure $4 \mathrm{~A})$. $\mathrm{CD} 31^{+}$cells incubated with media conditioned by $6 \times 10^{4} 435 \mathrm{~S}$ cells (varying conditioning times -30 min to $24 \mathrm{~h}$ ) on Matrigel indicated an initial $\sim 5$-fold induction burst of in vitro angiogenesis, which eventually returned to control-like levels after $24 \mathrm{~h}$. Generally, conditioning times up to $12 \mathrm{~h}$ significantly promoted $\mathrm{CD} 31^{+}$cell tubulogenesis $(P \leqslant 0.05$; Figure 4B)

The promotion of tubulogenesis by $12 \mathrm{~h} 435 \mathrm{~S}$ cell-conditioned media (varying cell number) was diminished $\sim 45-60 \%$ by $1 \mu \mathrm{M} \mathrm{EA}$, $\sim 20-30 \%$ by $1 \mu \mathrm{M}$ EGCG, and $\sim 5-35 \%$ by $1 \mu \mathrm{g} \mathrm{ml}^{-1}$ endostatin. Only the addition of EA to 435 S-conditioned medium significantly reduced this cell number-dependent angiogenesis relative to controls $(P \leqslant 0.05$; Figure $4 \mathrm{C})$. Using a luciferin-luciferase ATP
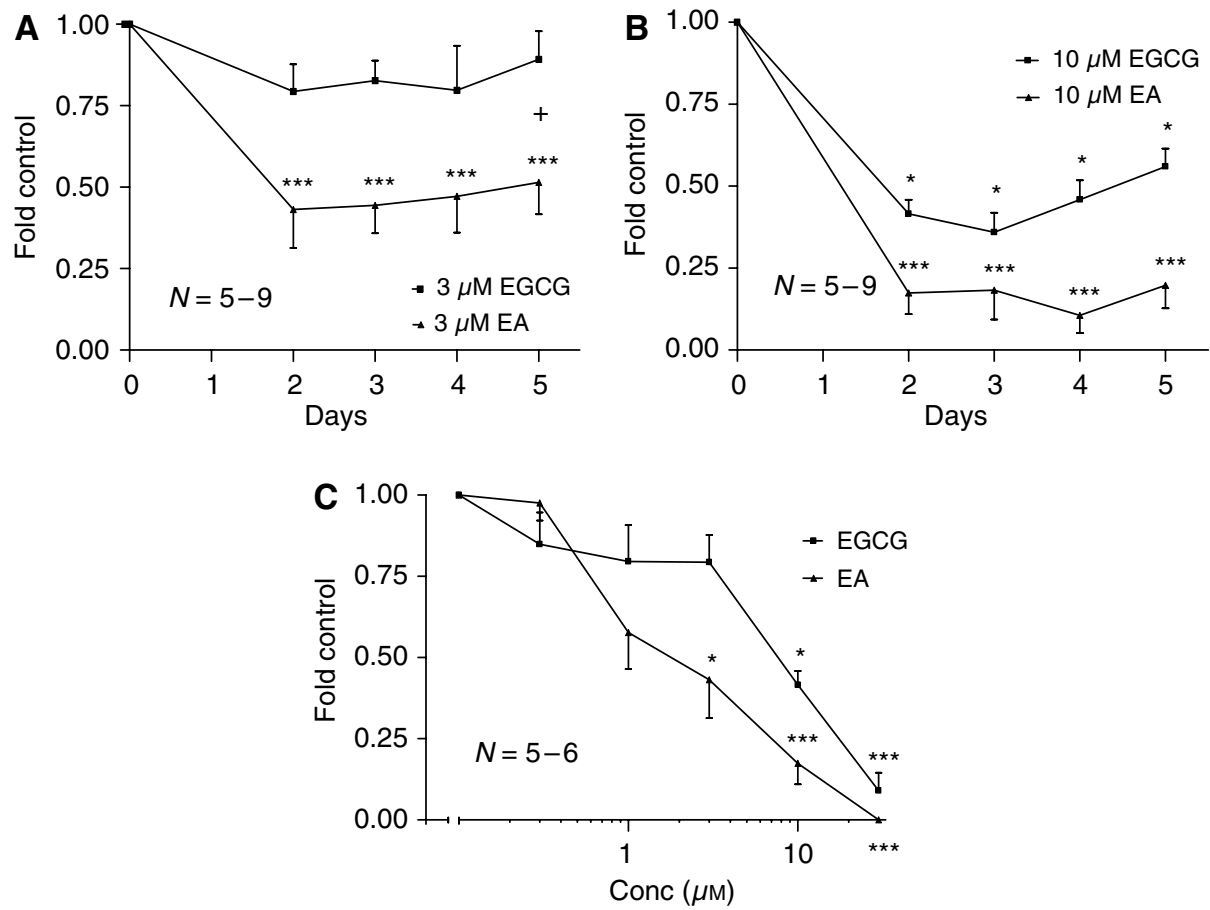

Figure 2 Epigallocatechin gallate (EGCG) and ellagic acid (EA) inhibit human breast cancer growth in vitro. (A and B) EA treatment reduced cell number when compared to equimolar amounts of EGCG. (C) EA treatment over 2 days reduced cell number at one half-log higher potency than EGCG. Control; $435 \mathrm{~S}$ cells incubated in CDMEM supplemented with I0\% FBS. Control mean $=212806 \pm 35642435 \mathrm{~S}$ cells. 

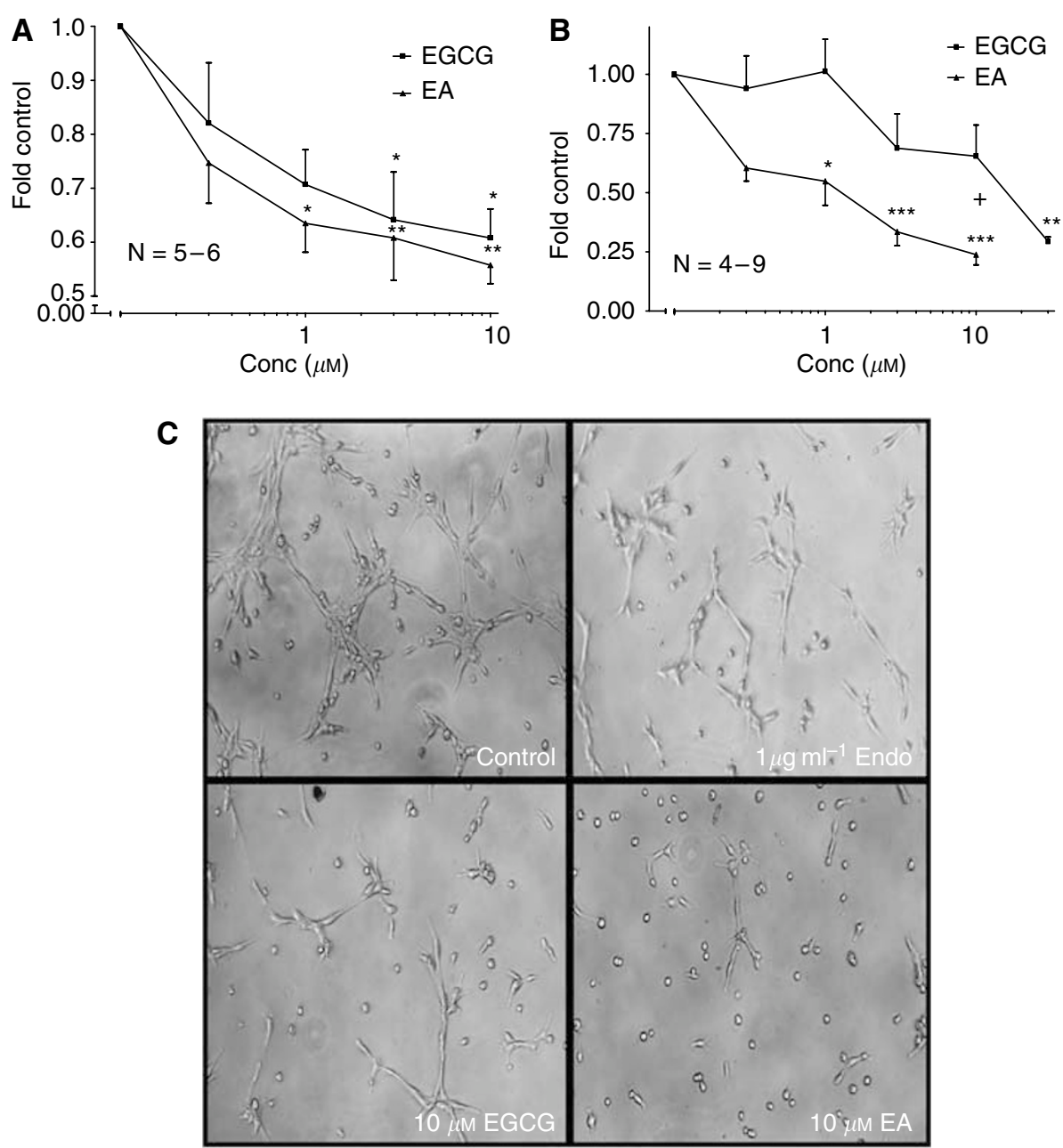

Figure 3 Epigallocatechin gallate (EGCG) and ellagic acid (EA) inhibit human EC growth and angiogenesis in vitro. (A) Both EGCG and EA reduced $\left.\mathrm{CD}\right|^{+}$cell number when incubated for $24 \mathrm{~h}$ at $\geqslant 1 \mu \mathrm{M}$. Control $\mathrm{A}$ mean $=163094 \pm\left. 27859 \mathrm{CD} 3\right|^{+}$cells. (B) EA was more potent than EGCG in reducing $\mathrm{CD} \mathrm{I}^{+}$cell tubulogenesis over $6 \mathrm{~h}$. Control B mean $=12078.1 \pm 3355.3$ angiogenesis units. (C) Representative images illustrating endostatin, EGCG, and EA inhibition of tubule-like formations ( $\times 100$ magnification). Control; CD31 ${ }^{+}$cells incubated in CDMEM supplemented with I0\% FBS.

detection assay we also determined that $0.1-1.0 \mu \mathrm{g} \mathrm{ml}^{-1}$ endostatin, our antiangiogenic control, did not inhibit the activity of $435 \mathrm{~S}$ secreted NDPK-B (data not shown) in contrast to EGCG and EA. Overall, $1 \mu \mathrm{M}$ EA produced better inhibition of in vitro angiogenesis induced by MDA-MB- 435 S cells than equimolar EGCG.

The observed promotion of tubulogenesis by $60-\mathrm{min}$ conditioned media $\left(6 \times 10^{4}\right.$ 435S cells; $P \leqslant 0.05$; Figure $\left.4 \mathrm{D}\right)$ was attenuated back to control levels with the addition of $0.75 \mathrm{U}$ apyrase per ml media. This degradation of nucleotides (i.e., ATP and ADP) by the apyrase enzyme blocked the $\sim 2.9$-fold induction above controls. The addition of apyrase to non-conditioned control media had no effect (data not shown).

\section{Purified and MDA-MB-435S secreted NDPK induce angiogenesis}

Incubation of $\mathrm{CD} 31^{+}$cells for $24 \mathrm{~h}$ with semi-pure and purified bovine liver NDPK (activity matched to $1 \times 435 \mathrm{~S}$ cell-secreted NDPK extract) increased in vitro angiogenesis at least $\sim 1.7-$ and $\sim 1.3$-fold above control levels, respectively (Figure 5A and B). Angiogenic stimulation control EGM-2 further stimulated tubulogenesis two-fold above control. The semi-pure bovine liver NDPK was purified $\sim 12.5$-fold, based on specific transphosphorylation activities, using an EDA-ATP sepharose column (Jena Bioscience, Germany). The combination of bovine liver NDPK, GTP (donor), and ADP (acceptor) induced tubulogenesis greater than that of NDPK alone. GTP and ADP alone induced a modest increase in tubulogenesis consistent with $\mathrm{P} 2 \mathrm{Y}$ receptor activation (data not shown).

Progressive immunodepletion of NDPK-B from the 435S cellsecreted NDPK extract suppressed $\mathrm{CD} 31^{+}$cell tubulogenesis on collagen up to $65 \%$ when compared to non-depleted extract (Figure 5C), the depleted transphosphorylation activities were measured and compared to starting material using the luciferinluciferase ATP detection assay. The significant increase in angiogenesis induced by $435 \mathrm{~S}$ cell-secreted NDPK extract at $24 \mathrm{~h}$ was similar to the $\sim 2.0$-fold stimulation seen with $10 \mu \mathrm{M} 2 \mathrm{MS}$-ATP or $100 \mu \mathrm{M}$ ATP $(P \leqslant 0.01$; Figure $5 \mathrm{D})$ and blocked by $10 \mu \mathrm{M}$ MRS2179 ( $\sim 1.2$-fold control). The 72-h assay produced a $\sim 2.3$ fold increase in tubulogenesis after the addition of NDPK extract $(P \leqslant 0.05$; Figure $5 \mathrm{E})$ and a reduction back to $\sim 1.3$-fold in the presence of $10 \mu \mathrm{M}$ MRS2179.

\section{P2Y receptor activation on human ECs stimulates angiogenesis}

$\mathrm{CD}^{+}{ }^{+}$cells incubated for $24 \mathrm{~h}$ with $10 \mu \mathrm{M}$ 2MS-ATP $\left(\mathrm{P} 2 \mathrm{Y}_{1} \mathrm{R}\right.$ agonist) or $100 \mu \mathrm{M}$ ATP $\left(\mathrm{P}_{2} \mathrm{Y}_{1 / 2} \mathrm{R}\right.$ agonist) indicate a similar, significant $\sim 2.0$-fold induction of in vitro angiogenesis above control levels comparable to the angiogenic stimulation control 


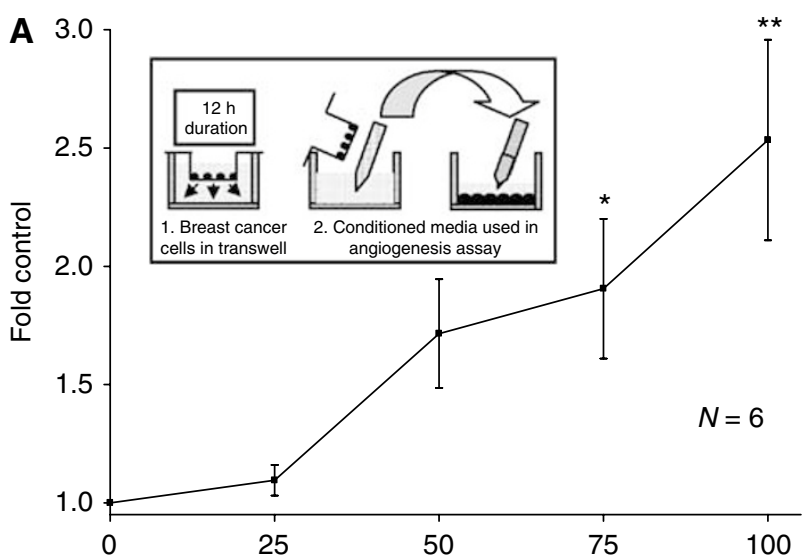

No. of $435 \mathrm{~S}$ human BCa cells per $\mu$ l of conditioned media

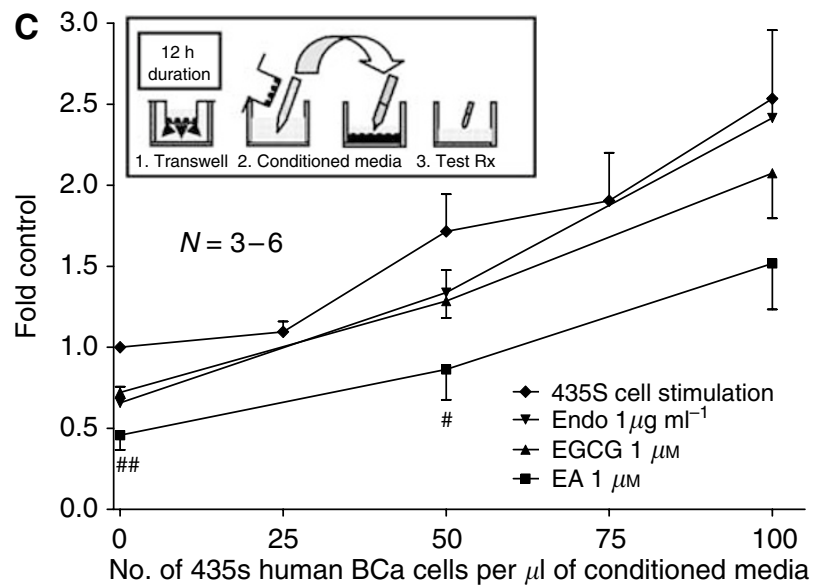

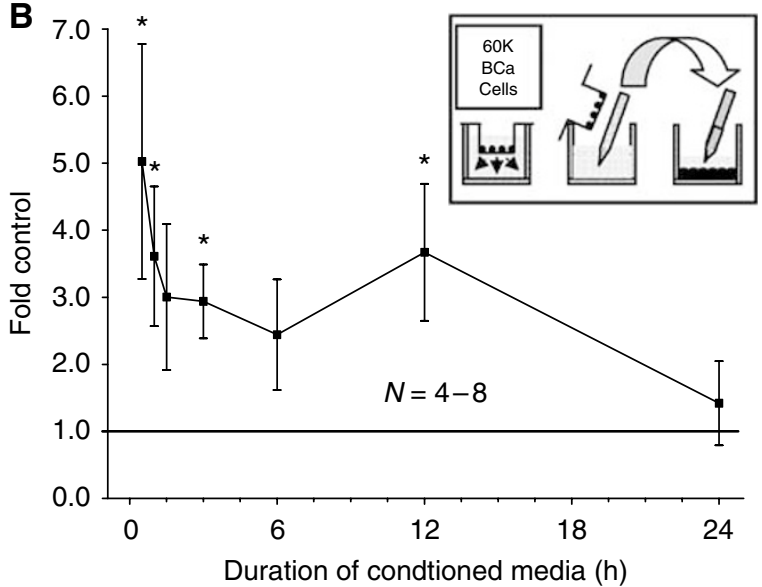

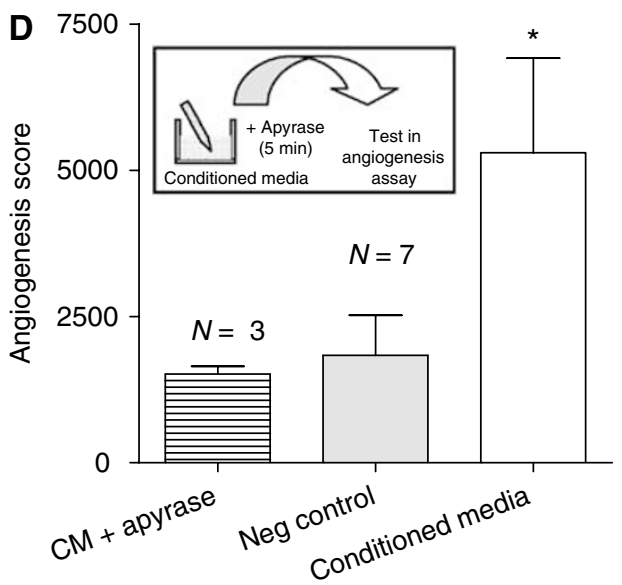

Figure 4 Human breast cancer cell-conditioned media promotes in vitro angiogenesis. CD3I ${ }^{+}$EC were incubated on Matrigel ${ }^{\mathrm{TM}}$ with media conditioned by MDA-MB-435S cells (varying conditioning time or cell number) and tubulogenesis was observed after $6 \mathrm{~h}$. (A) increasing $435 \mathrm{~S}$ cell number induced in vitro angiogenesis. Control A consisted of CDMEM supplemented with $10 \%$ FBS and conditioned for I $2 \mathrm{~h}$ with no $435 \mathrm{~S}$ cells. Control mean $=258 \mathrm{I} .5 \pm 374.6$ angiogenesis units. (B) shorter $435 \mathrm{~S}$ cell conditioning time stimulated in vitro angiogenesis. Control $\mathrm{B}$ consisted of CDMEM conditioned for $24 \mathrm{~h}$ with no $435 \mathrm{~S}$ cells. Control mean $=3373.0 \pm 1179.3$ angiogenesis units. (C) Ellagic acid (EA) but not epigallocatechin gallate (EGCG) or endostatin treatment diminished $435 \mathrm{~S}$ cell number dependent in vitro angiogenesis. Control C consisted of CDMEM conditioned for $24 \mathrm{~h}$ with no $435 \mathrm{~S}$ cells. Control mean $=12229.1 \pm 5573.4$ angiogenesis units. (D) Addition of apyrase to 4355 cell-conditioned media blocked its ability to stimulate in vitro angiogenesis. Control D consisted of CDMEM conditioned for 60 min with no 4355 cells.

EGM-2 (containing VEGF) $(P \leqslant 0.001$; Figure $5 \mathrm{D}) . \mathrm{CD}^{+} 1^{+}$cells incubated for $72 \mathrm{~h}$ with $100 \mu \mathrm{M}$ ATP demonstrate a significant $\sim 2.5$-fold induction of tubulogenesis above control levels, while the EGM-2 control produced a $\sim 3$.6-fold increase over control $(P \leqslant 0.05$; Figure $5 \mathrm{E})$. The use of $100 \mu \mathrm{M} 2 \mathrm{MS}-\mathrm{ATP}$ and $1 \mathrm{mM}$ ATP produced no increase in stimulation over $10 \mu \mathrm{M} 2 \mathrm{MS}-\mathrm{ATP}$ or $100 \mu \mathrm{M}$ ATP alone (data not shown). The addition of $10 \mu \mathrm{M}$ MRS2179 (P2Y ${ }_{1} \mathrm{R}$ antagonist) to either $10 \mu \mathrm{M} 2 \mathrm{MS}-\mathrm{ATP}$ or $100 \mu \mathrm{M}$ ATP stimulations diminished tubulogenesis back to near control levels (Figure 5D) after $24 \mathrm{~h}$, while the addition of this $\mathrm{P} 2 \mathrm{Y}_{1} \mathrm{R}$ antagonist over a $72 \mathrm{~h}$ period only suppressed ATP angiogenic stimulation back down to $\sim 1.5$-fold that of control (Figure 5E). MRS2179 $(10 \mu \mathrm{M})$ showed no effect on tubulogenesis by itself (data not shown). We chose $10 \mu \mathrm{M}$ MRS2179 as maximal inhibition of $\mathrm{P}_{2} \mathrm{Y}_{1}$ receptor activation on ECs, consistent with our findings and those of others (Boyer et al, 1998; Baurand et al, 2001; Kaiser and Buxton, 2001, 2002) in EC systems. Varying concentrations of MRS2179 $(0.1-10 \mu \mathrm{M})$ did not affect NDPK transphosphorylation activity (data not shown), indicating $\mathrm{P} 2 \mathrm{Y}_{1} \mathrm{R}$ antagonism as the primary mode of angiogenic inhibition.

\section{DISCUSSION}

Our results demonstrate that both EA and EGCG inhibit MDA-MB$435 \mathrm{~S}$ human breast cancer cell growth in a dose-dependent manner, consistent with the results of others (Suganuma et al, 1999; Seeram et al, 2005). Both EGCG and EA are near equipotent in suppressing $\mathrm{CD} 31^{+} \mathrm{EC}$ in vitro angiogenesis and $435 \mathrm{~S}$ cell growth, while less potent in inhibiting $\mathrm{CD} 31^{+}$EC growth. The disparate effect of polyphenols between EC growth inhibition and tubulogenesis suppression suggests that P2Y signalling may be critical in the complex process of tubulogenesis, while EC growth could be less dependent on P2Y mediated effects of these compounds. Therefore, we utilised the $\mathrm{CD} 31^{+}$cell tubulogenesis assay as a measure reflecting in vivo angiogenesis.

We observed that $435 \mathrm{~S}$ cells promote in vitro angiogenesis in a cell number dependent manner. Furthermore, EA > EGCG attenuated this proangiogenic effect. The initial antiangiogenic properties attributed to EA and EGCG (when incubated with non-conditioned media) are distinct from their increasing capacity to suppress the $\mathrm{CD} 1^{+}$cell tubulogenesis promoted by increasing numbers of $435 \mathrm{~S}$ cells, thus suggesting another mode of action. Given that 

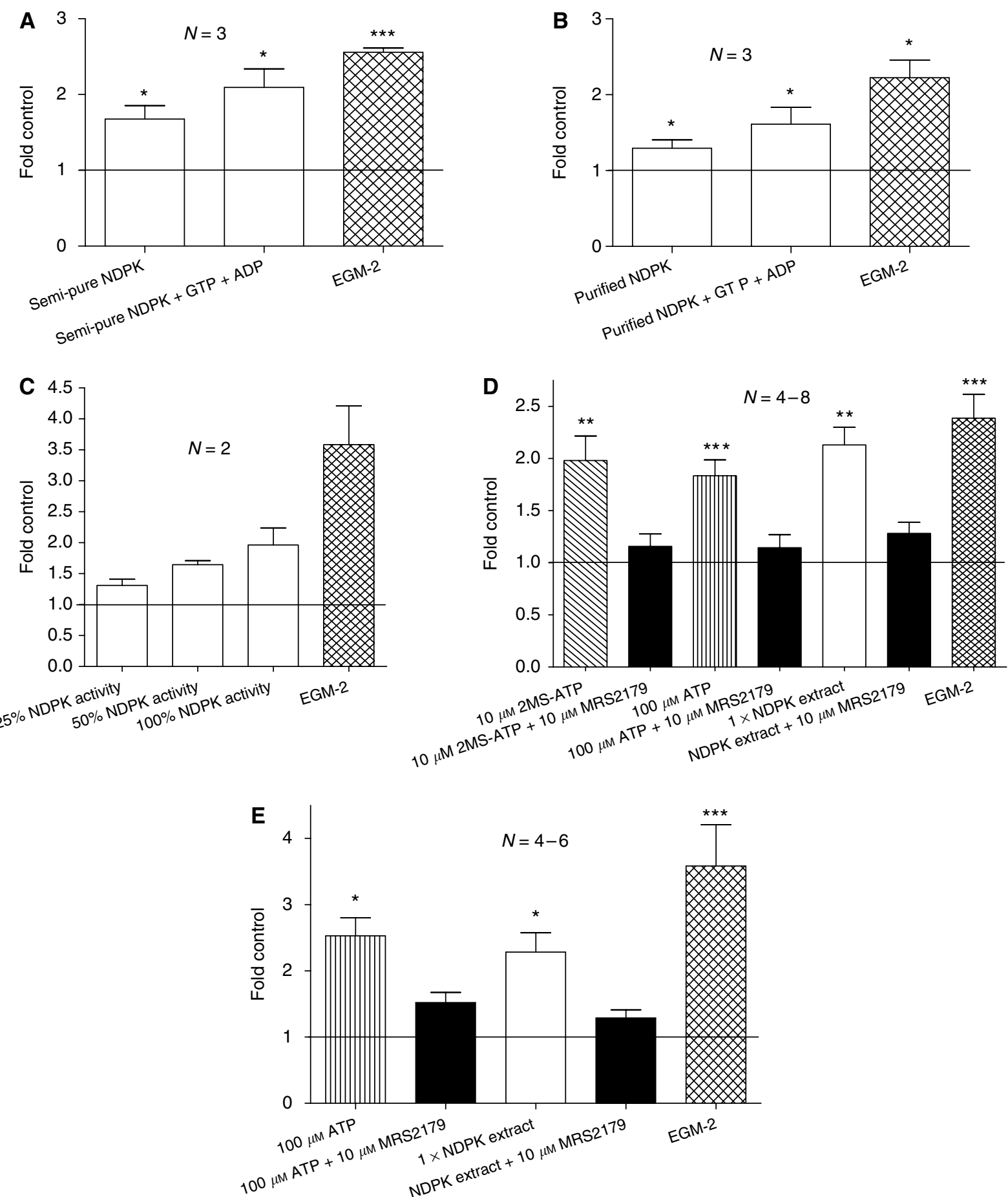

Figure 5 Extracellular nucleoside diphosphate kinase (NDPK) and EC P2Y, receptor activation induce angiogenesis in vitro. (A and B) semi-pure as well as purified bovine liver NDPK induced CD31 ${ }^{+}$cell tubulogenesis over $24 \mathrm{~h}$. Statistical significance versus control was determined using the Mann-Whitney test. (C) NDPK-B derived from $435 \mathrm{~S}$ cell-secreted NDPK extract promoted in vitro angiogenesis over $72 \mathrm{~h}$ at various depletion levels. Control C mean $=2645.9$ angiogenesis units. (D) $24 \mathrm{~h}$ incubation with ATP, 2MS-ATP, and NDPK extract all stimulated angiogenesis; blocked by MRS2 I 79. Control D mean $=6183.8 \pm 1840.4$ angiogenesis units. (E) $72 \mathrm{~h}$ incubation with ATP and NDPK extract both promoted angiogenesis; blocked by P2Y, R antagonist, MRS2 179. Control $E$ mean $=1256.6 \pm 240.9$ angiogenesis units. Controls consisted of CD31 ${ }^{+}$cells incubated in CDMEM supplemented with $2 \%$ FBS. The angiogenic stimulation control used was endothelial growth media-2 (EGM-2 $\left.{ }^{\mathrm{TM}}\right)$ containing VEGF.

EGCG has been shown to inhibit cancer-associated enzymes such as matrix metalloproteinases (MMPs) (Yamakawa et al, 2004) and the proteasome (Kazi et al, 2004), we suggest that EGCG and EA inhibition of secreted NDPK-B is another anticancer and antiangiogenic property that can be attributed to these polyphenolic compounds. We propose that EA's potency as an
NDPK-B inhibitor and the subsequent reduction of extracellular ATP levels (Yang et al, 1994; Malmquist et al, 2001) may, in part explain why EA is a more potent inhibitor of $\mathrm{CD}^{+} 1^{+}$cell tubulogenesis than is EGCG. Known antiangiogenic levels of endostatin did not inhibit NDPK transphosphorylation activity and its diminishing effectiveness in suppressing in vitro angiogenesis 
in response to increasing numbers of $435 \mathrm{~S}$ cells, further suggests that breast cancer cell-secreted NDPK may play an important role in promoting angiogenesis. One other possible explanation consistent with our hypothesis would be that these compounds also block the activation of nucleotide receptors. However, radioligand binding competition studies with $\mathrm{EC} P 2 \mathrm{Y}_{1} \mathrm{R}$ do not support this possibility (data not shown). Epigallocatechin gallate and EA are potent but non-specific inhibitors of NDPK transphosphorylation activity; therefore, we explored further the extracellular nucleotide aspect of our secreted NDPK angiogenesis model. Supporting this hypothesis, we found that the degradation of ATP and ADP by apyrase suppressed the ability of $435 \mathrm{~S}$ cellconditioned media to induce in vitro angiogenesis.

We observed decreased tubulogenesis levels with increasing conditioning durations with $435 \mathrm{~S}$ cells. This negative correlation is not clear mechanistically, but does not argue against the presence of a paracrine and/or autocrine proangiogenic effect in vivo since if in the blood stream, such effects would be expected to take place adjacent to endothelium diluted by blood flow and thus would not accumulate but would be replenished by NDPK-B protein secretion.

Nucleoside diphosphate kinase's extracellular role may be underappreciated in carcinogenesis especially in tumour angiogenesis, as indicated by the plethora of studies involving only its intracellular actions. The secretion of NDPK orthologues by intracellular parasites as a possible survival tactic (Gounaris et al, 2001; Chopra et al, 2003) and the secretion of NDPK by various solid and haematological malignancies (Anzinger et al, 2001; OkabeKado and Kasukabe, 2003) lead us to propose the pathological role of secreted NDPK in promoting cancer and tumour angiogenesis. Extracellular NDPK in the tumour vasculature would elevate nucleotide signalling and subsequent release of vasoactive factors with angiogenic effects (Ziche and Morbidelli, 2000). In support of our hypothesis, a positive correlation between the regulation of P2Y signalling and various angiogenic properties (Moser et al, 2001; Tanaka et al, 2004; Kaczmarek et al, 2005) is known.

Our results with purified NDPK, (a mixture of NDPK-A and -B), together with the observation that both NDPK isoforms are secreted by various cancers suggests that the transphosphorylation activity of NDPK and not its isoform is crucial. We tested human breast cancer secreted NDPK and observed that NDPK-B depletion from $435 \mathrm{~S}$ cell-secreted NDPK extract progressively reduced its ability to promote $\mathrm{CD} 31^{+}$cell tubulogenesis. The release of NDPK into the incubation buffer is not the result of cell death, since we determined that greater than $10 \%$ of cells would need to undergo complete lysis (not apoptosis) during our $90 \mathrm{~min}$ collection to obtain similar levels of transphosphorylation activity to NDPK extracts (data not shown). Moreover, when examined after extract collection, cultures are healthy and can be returned to the incubator and observed to be viable. ATP synthase does not account for ATP production as we used an extract devoid of intact cells or membranes. Conditioned media did not contain adenylate kinase activity. Autophosphorylation assays (Backer et al, 1993) have been used to monitor NDPK transphosphorylation activity; we employed a phosphoryl transfer assay because it produces kinetic data and can determine relative inhibition. The transphosphorylation activity assay has shown that 435S NDPK-B extract and purified bovine liver NDPK have approximately the same $K_{\mathrm{m}}(\sim 30 \mu \mathrm{M})$ for ADP (Anzinger et al, 2001).

We observed that $435 \mathrm{~S}$ cell-secreted NDPK extract and $\mathrm{P} 2 \mathrm{Y}_{1} \mathrm{R}$ activation induce significant in vitro angiogenesis and do so to a similar degree. The use of $10 \mu \mathrm{M} 2 \mathrm{MS}$-ATP or $100 \mu \mathrm{M}$ ATP in promoting $\mathrm{CD} 31^{+}$cell tubule-like formations was maximal, likely due to known desensitisation of $\mathrm{P} 2 \mathrm{Y}_{1 / 2}$ receptors at higher agonist concentrations (Ralevic and Burnstock, 1998). MRS2179 blockade of $\mathrm{CD}_{31}{ }^{+}$cell $\mathrm{P} 2 \mathrm{Y}_{1} \mathrm{R}$ activation stimulated with $435 \mathrm{~S}$ cell-secreted NDPK extract provides strong evidence that human breast cancersecreted NDPK reaction product provides a proangiogenic signal via P2YR activation (e.g., ATP). The addition of MRS2179 still allowed minimal angiogenic stimulation over negative control, suggesting that P2Y signalling works in concert with other angiogenic pathway(s) that are yet to be elucidated.

The role of $n m 23-H 2$ in promoting metastasis is supported by the observation that a catalytically inactive mutant of NDPK-B significantly suppressed the lung metastasis of human melanoma cells in vivo (Hamby et al, 2000). Recent work indicates that activated $\mathrm{P} 2 \mathrm{Y}_{2} \mathrm{R}$ 's associate and transactivate vascular endothelial growth factor receptor-2 (VEGFR2) (Seye et al, 2004), directly linking nucleotide receptor activation to established tumour angiogenesis signalling (VEGF-VEGFR signalling). P2Y receptor potentiation of VEGFR2 signalling therefore may be essential in describing the angiogenic properties of nucleotides such as ATP. P2Y and VEGF receptors being colocalised to caveolar domains in the cell membrane allows the potential of a substantial proangiogenic signal with small amounts of agonist stimulation (Kaiser et al, 2002).

$\mathrm{P} 2 \mathrm{YR}$ signalling is a tumour angiogenesis and metastasis mechanism which $435 \mathrm{~S}$ cells exploit. Since cells secrete prephosphorylated NDPK-B (Anzinger et al, 2001), ATP generation locally in vivo may require little substrate and donor (a triphosphonucleotide such as GTP) may be intracellular. Our model predicts two spatially distinct yet conceptually dependent mechanisms: NDPK recycling of ADP back to ATP in both arteries and capillaries. Nucleoside diphosphate kinase in the arteries may elevate local nucleotide ATP concentrations to produce P2YRmediated vasodilation and anti-platelet aggregation, advantageous to the transit of cancer cells to secondary sites. Nucleoside diphosphate kinase secretion in capillaries may elevate local nucleotide concentrations and produce nucleotide receptor (e.g., P2Y) mediated angiogenesis (Figure 6). As an example supporting this hypothesis we provide evidence that extracellular NDPK induces EC tubulogenesis predominately via $\mathrm{P} 2 \mathrm{Y}_{1} \mathrm{R}$. Elevated levels of ATP and subsequent P2YR activation will release additional ATP to prolong the angiogenic effect (Yang et al, 1994). The constant elaboration of NDPK-B by $435 \mathrm{~S}$ cells facilitates the chronic and increased activation of $\mathrm{P} 2 \mathrm{Y}$ signalling, producing pathological angiogenesis in tumour vasculature. Since the NDPK-B enzyme can be expressed as both an ecto- or exo-enzyme and help to regenerate $8-12 \%$ of ADP in blood back to ATP (Buxton et al, 2001), it may play a significant role in angiogenic regulation especially in the setting of apoptosis and necrosis

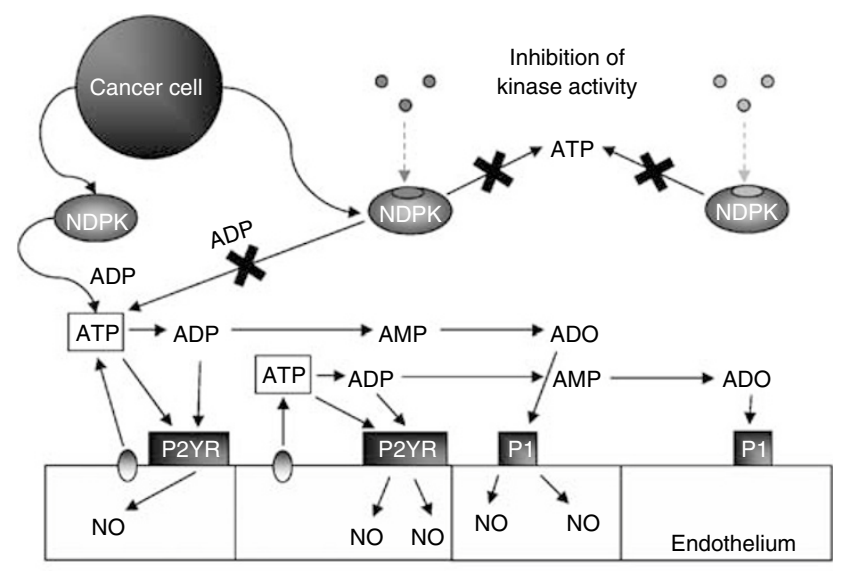

Cancer cell NDPK $\rightarrow$ ATP $\rightarrow$ Tumour angiogenesis $\rightarrow$ Metastasis?

Figure 6 Putative role of extracellular nucleoside diphosphate kinase (NDPK) and P2Y receptor activation in tumour angiogenesis. We hypothesise that breast cancer secreted NDPK-B is an important contributor to promoting angiogenesis and metastasis. Extracellular NDPK would modulate nucleotides such as elevating ATP levels. This scenario would subsequently lead to P2Y purinergic receptor activation above an unknown threshold to produce conditions favorable to pathological angiogenesis. 
associated with tumour growth as a source of triphosphonucleotide donor.

We are aware that $435 \mathrm{~S}$ carcinoma cells exhibit both breast cancer and melanoma characteristics (Sellappan et al, 2004). This fact strengthens our observation that NDPK-P2Y angiogenic signalling may be utilised in a broad range of tumours. P2Y receptor signalling has also been observed to modulate proliferation of various carcinomas in a positive, and negative fashion (White and Burnstock, 2006). One possible explanation is that

\section{REFERENCES}

Anzinger J, Malmquist NA, Gould J, Buxton IL (2001) Secretion of a nucleoside diphosphate kinase (Nm23-H2) by cells from human breast, colon, pancreas and lung tumors. Proc West Pharmacol Soc 44: 61-63

Backer JM, Mendola CE, Kovesdi I, Fairhurst JL, O’Hara B, Eddy Jr RL, Shows TB, Mathew S, Murty VV, Chaganti RS (1993) Chromosomal localization and nucleoside diphosphate kinase activity of human metastasis-suppressor genes NM23-1 and NM23-2. Oncogene 8: 497-502

Baurand A, Raboisson P, Freund M, Leon C, Cazenave JP, Bourguignon JJ, Gachet C (2001) Inhibition of platelet function by administration of MRS2179, a P2Y1 receptor antagonist. Eur J Pharmacol 412: 213-221

Bertheau P, De La RA, Steeg PS, Merino MJ (1994) NM23 protein in neoplastic and nonneoplastic thyroid tissues. Am J Pathol 145: 26-32

Boyer JL, Mohanram A, Camaioni E, Jacobson KA, Harden TK (1998) Competitive and selective antagonism of P2Y1 receptors by N6-methyl $2^{\prime}$-deoxyadenosine $3^{\prime}, 5^{\prime}$-bisphosphate. Br J Pharmacol 124: 1-3

Buxton IL, Kaiser RA, Oxhorn BC, Cheek DJ (2001) Evidence supporting the nucleotide axis hypothesis: ATP release and metabolism by coronary endothelium. Am J Physiol Heart Circ Physiol 281: H1657-H1666

Cao Y, Cao R (1999) Angiogenesis inhibited by drinking tea. Nature 398: 381 Chopra P, Singh A, Koul A, Ramachandran S, Drlica K, Tyagi AK, Singh Y (2003) Cytotoxic activity of nucleoside diphosphate kinase secreted from Mycobacterium tuberculosis. Eur J Biochem 270: 625-634

Clinical Trials (2006) Current avastin clinical trials. http://clinicaltrials.gov/

Goepfert C, Sundberg C, Sevigny J, Enjyoji K, Hoshi T, Csizmadia E, Robson S (2001) Disordered cellular migration and angiogenesis in cd39-null mice. Circulation 104: 3109-3115

Gounaris K, Thomas S, Najarro P, Selkirk ME (2001) Secreted variant of nucleoside diphosphate kinase from the intracellular parasitic nematode Trichinella spiralis. Infect Immun 69: 3658-3662

Hamby CV, Abbi R, Prasad N, Stauffer C, Thomson J, Mendola CE, Sidorov V, Backer JM (2000) Expression of a catalytically inactive H118Y mutant of $\mathrm{nm} 23-\mathrm{H} 2$ suppresses the metastatic potential of line IV Cl 1 human melanoma cells. Int J Cancer 88: 547 - 553

Holmgren L, O'Reilly MS, Folkman J (1995) Dormancy of micrometastases: balanced proliferation and apoptosis in the presence of angiogenesis suppression. Nat Med 1: 149-153

Jain RK (2001) Normalizing tumor vasculature with anti-angiogenic therapy: a new paradigm for combination therapy. Nat Med 7: 987-989

Kaczmarek E, Erb L, Koziak K, Jarzyna R, Wink MR, Guckelberger O, Blusztajn JK, Trinkaus-Randall V, Weisman GA, Robson SC (2005) Modulation of endothelial cell migration by extracellular nucleotides: involvement of focal adhesion kinase and phosphatidylinositol 3-kinasemediated pathways. Thromb Haemost 93: 735-742

Kaiser RA, Buxton IL (2001) Endothelium-dependent, MRS2179-independent actions of uridine $5^{\prime}$-triphosphate in guinea pig aorta. Proc West Pharmacol Soc 44: 49-51

Kaiser RA, Buxton IL (2002) Nucleotide-mediated relaxation in guinea-pig aorta: selective inhibition by MRS2179. Br J Pharmacol 135: 537-545

Kaiser RA, Oxhorn BC, Andrews G, Buxton IL (2002) Functional compartmentation of endothelial P2Y receptor signaling. Circ Res 91: $292-299$

Kashiwagi S, Izumi Y, Gohongi T, Demou ZN, Xu L, Huang PL, Buerk DG, Munn LL, Jain RK, Fukumura D (2005) NO mediates mural cell recruitment and vessel morphogenesis in murine melanomas and tissueengineered blood vessels. J Clin Invest 115: 1816-1827

Kazi A, Wang Z, Kumar N, Falsetti SC, Chan TH, Dou QP (2004) Structureactivity relationships of synthetic analogs of (-)-epigallocatechin3-gallate as proteasome inhibitors. Anticancer Res 24: 943-954 these differing effects on proliferation reflect which cancers pathologically secrete NDPK.

\section{ACKNOWLEDGEMENTS}

This work was financially supported by a grant from Clayton Foundation for Research to ILOB and NIH T32 Research Traineeship to SR.
Liang YC, Chen YC, Lin YL, Lin-Shiau SY, Ho CT, Lin JK (1999) Suppression of extracellular signals and cell proliferation by the black tea polyphenol, theaflavin-3,3'-digallate. Carcinogenesis 20: 733-736

Malmquist NA, Anzinger JJ, Hirzel D, Buxton IL (2001) Ellagic acid inhibits nucleoside diphosphate kinase-B activity. Proc West Pharmacol Soc 44: $57-59$

Moser TL, Kenan DJ, Ashley TA, Roy JA, Goodman MD, Misra UK, Cheek DJ, Pizzo SV (2001) Endothelial cell surface F1-F0 ATP synthase is active in ATP synthesis and is inhibited by angiostatin. Proc Natl Acad Sci USA 98: $6656-6661$

Nickel W (2003) The mystery of nonclassical protein secretion. A current view on cargo proteins and potential export routes. Eur J Biochem 270: $2109-2119$

Okabe-Kado J, Kasukabe T (2003) Physiological and pathological relevance of extracellular NM23/NDP kinases. J Bioenerg Biomembr 35: 89-93

Postel EH (2003) Multiple biochemical activities of NM23/NDP kinase in gene regulation. J Bioenerg Biomembr 35: 31-40

Ralevic V, Burnstock G (1998) Receptors for purines and pyrimidines. Pharmacol Rev 50: 413-492

Roymans D, Willems R, Van Blockstaele DR, Slegers H (2002) Nucleoside diphosphate kinase (NDPK/NM23) and the waltz with multiple partners: possible consequences in tumor metastasis. Clin Exp Metastasis 19: 465-476

Seeram NP, Adams LS, Henning SM, Niu Y, Zhang Y, Nair MG, Heber D (2005) In vitro antiproliferative, apoptotic and antioxidant activities of punicalagin, ellagic acid and a total pomegranate tannin extract are enhanced in combination with other polyphenols as found in pomegranate juice. J Nutr Biochem 16: $360-367$

Sellappan S, Grijalva R, Zhou X, Yang W, Eli MB, Mills GB, Yu D (2004) Lineage infidelity of MDA-MB-435 cells: expression of melanocyte proteins in a breast cancer cell line. Cancer Res 64: 3479-3485

Seye CI, Yu N, Gonzalez FA, Erb L, Weisman GA (2004) The P2Y2 nucleotide receptor mediates vascular cell adhesion molecule-1 expression through interaction with VEGF receptor-2 (KDR/Flk-1). J Biol Chem 279: 35679-35686

Singh AK, Seth P, Anthony P, Husain MM, Madhavan S, Mukhtar H, Maheshwari RK (2002) Green tea constituent epigallocatechin-3-gallate inhibits angiogenic differentiation of human endothelial cells. Arch Biochem Biophys 401: 29-37

Suganuma M, Okabe S, Kai Y, Sueoka N, Sueoka E, Fujiki H (1999) Synergistic effects of $(-)$-epigallocatechin gallate with (-)-epicatechin, sulindac, or tamoxifen on cancer-preventive activity in the human lung cancer cell line PC-9. Cancer Res 59: 44-47

Tanaka N, Kawasaki K, Nejime N, Kubota Y, Nakamura K, Kunitomo M, Takahashi K, Hashimoto M, Shinozuka K (2004) P2Y receptor-mediated $\mathrm{Ca}(2+)$ signaling increases human vascular endothelial cell permeability. $J$ Pharmacol Sci 95: 174-180

Tong RT, Boucher Y, Kozin SV, Winkler F, Hicklin DJ, Jain RK (2004) Vascular normalization by vascular endothelial growth factor receptor 2 blockade induces a pressure gradient across the vasculature and improves drug penetration in tumors. Cancer Res 64: 3731-3736

White N, Burnstock G (2006) P2 receptors and cancer. Trends Pharmacol Sci 27: $211-217$

Yamakawa S, Asai T, Uchida T, Matsukawa M, Akizawa T, Oku N (2004) (-)-Epigallocatechin gallate inhibits membrane-type 1 matrix metalloproteinase, MT1-MMP, and tumor angiogenesis. Cancer Lett 210: 47-55

Yang S, Cheek DJ, Westfall DP, Buxton IL (1994) Purinergic axis in cardiac blood vessels. Agonist-mediated release of ATP from cardiac endothelial cells. Circ Res 74: $401-407$

Ziche M, Morbidelli L (2000) Nitric oxide and angiogenesis. J Neurooncol 50: $139-148$ 